\title{
A BIOGAS PRODUCTION UNIT FOR USE IN RURAL AREAS
}

\author{
${ }^{1 *}$ Agbetoye, L.A.S and ${ }^{2}$ Kusimo, I. O
}

Abstract - A biogas production unit was designed, fabricated and tested. It consists of a 168-litres anaerobic digester and a 38-litres gas storage tank connected together with $19 \mathrm{~mm}$ PVC pipes and locks. The digester and the separator tanks were fabricated from a high torsional strength $20 \mathrm{~mm}$ x $20 \mathrm{~mm}$ x $4 \mathrm{~mm}$ mild steel sheet supported by $60 \mathrm{~mm} \times 60 \mathrm{~mm} \times 4 \mathrm{~mm}$ angle iron welded together. Filler paste was applied to the two tanks for air tightness. The digester has a $900 \mathrm{~mm}$ shaft with blades attached that stirs the substrate. The machine is powered by a $0.75 \mathrm{~kW}$ electric motor connected to the side of the digester tank. A rubber seal was attached to the top of the stirrer to prevent the escape of gas from the tank. A pressure gauge and a gas connecting hose were attached for the measurement of the amount of gas produced, stored and released to the cooker respectively. Air and water tightness tests were carried out to avoid unnecessary leakage at any point.

Plant and animal wastes were utilized as feedstock for the biogas plant. A $50 \mathrm{~kg}$ of blended water hyacinth and 100 litres of water were fed as feedstock in the digester. The result after 4 days retention was 0.178 bar. Further, a mixture of $70 \mathrm{~kg}$ pig dung, poultry droppings and cow dung and 50 litres of water were also fed as the feedstock to the digester for another 4 days retention period. The result obtained from the pressure gauge was 0.307 bar. The mixture of both waste (45 kg of animal dung, $45 \mathrm{~kg}$ of blended water hyacinth and 55 litres of water) was also tested and the result obtained was 0.619 bar. From the result of the test, it was concluded that the mixture of plant and animal waste is the best feedstock for the digester to attain optimum production of methane gas.

Keywords - biogas, digester, separator tank, feedstock, methane

\section{Introduction}

Biogas is the gas produced by biological breakdown of organic matter [1]. It originated from biogenic materials which have been acted upon by bacteria. Production could be achieved through aerobic or anaerobic digestion of materials such as manure, sewage, municipal waste, green waste, plant material and energy crops [1]. The uses of biogas include the following;

i. domestic uses such as cooking and lighting;

ii. agricultural and industrial uses, specifically as fuel in stationary and mobile engines, to supply motive power, drive machinery or generate electricity; and

iii. to fuel automobile vehicles

\footnotetext{
${ }^{1,2}$ Department of Agricultural Engineering, Federal University ofTechnology, Akure, Ondo State,

Nigeria

*Corresponding Author
}

Biogas is a mixture of gases comprising 50\% - 60\% of Methane $\left(\mathrm{CH}_{4}\right), 20 \%$ - 30\% Carbon-dioxide $\left(\mathrm{CO}_{2}\right)$ and $10 \%$ $-20 \%$ of other gases such as Hydrogen sulphide $\left(\mathrm{H}_{2} \mathrm{~S}\right)$, Hydrogen gas $\left(\mathrm{H}_{2}\right)$, Nitrogen gas $\left(\mathrm{N}_{2}\right)$, Ammonia $\left(\mathrm{NH}_{3}\right)$, Carbon monoxide (CO) and other gases in traces. Methane is the target gas in the biogas, hence the need to purify the biogas generated to make it dry, flammable and odourless during usage. The presence of carbon dioxide makes the biogas poisonous. Hydrogen sulphide increases generation of sulphuric oxides which is acidic and corrosive. Ammonia gas leads to foul odour from the gas and carbon dioxide and water (moisture) reduces biogas flammability hence, it is necessary to forecast along the gas path sets of device such as gas filter and a water detector so as to get pure methane gas $\left(\mathrm{CH}_{4}\right)$.

Biogas technology has in the recent times also been viewed as a very good source of sustainable waste treatment/management, as disposal of wastes has become a major problem especially to the third world countries. The effluent of this process is residue, which is rich in essential inorganic elements needed for healthy plant growth known as bio-fertilizer which when applied to the soil enriches it with no detrimental effects on the environment [2]. The raw materials used in many places for the gas production include agricultural wastes such as animal manures and some crop residues. However, the rate and efficiency of digestion of feedstock depends on its physical and chemical form. Plant materials especially crop residues are more difficult to digest than animal manures. This is because hydrolysis of cellulose materials of crop residues is a slow process and can be a major rate determining step in anaerobic digestion process. Raw plant materials are bound up in plant cells usually strengthened with cellulose and lignin which are difficult to digest. In order to let the bacteria reach the more digestible foods, the plant material must be broken down $[3,4]$.

Furthermore, the imbalance in the ratio of carbon to nitrogen of the plant raw materials can limit the rate of organic conversion into methane. The most suitable plant species for biogas production are those rich in biodegradable carbohydrate such as sugars, lipids and proteins and poor in hemi-cellulose and lignin which are highly difficult to biodegrade [5]. Crop residues have been utilized for biogas production. These include: rice husk [6, 7], grass from different species [8] and other terrestrial plant wastes [9, 10]. Animal wastes that have been utilized for biogas production include cattle dung, poultry dung, pig dung, and swine dung $[11,12,13,14]$.

When designing an anaerobic digester at a specific site, it is important to understand the total energy demand required for digester function. Knowing the energy demand allows estimating the net energy available for other uses. There are many factors that affect heat exchange between an anaerobic digester and its surroundings. The primary factors include soil characteristics and conditions such as density, thermal 
conductivity, specific heat of the soil, temperature and moisture conditions of the ground. For example, a digester placed in dry sand will lose heat at a considerably slower rate than one exposed to saturated sand. Ground surface temperature is influenced by weather conditions and duration of exposure. The ground could be frozen to a certain depth depending on the severity of the weather, soil type and moisture content [4]. Understanding these factors would help designers/contractors in selecting an appropriate site for the system. There are two major energy demands for operating an anaerobic digester. The first is energy required to bring the influent manure up to the operating temperature. This energy demand will be significant in cold climate due to influent manure temperature, unless it is pre-heated. The second demand is energy required to maintain digester operating temperature. Heat loss through the walls, floor and cover must be balanced by adding maintenance heat.

The heat loss through the walls, floor and cover are dependent upon material type used for construction, insulation type and thickness as well as the temperature and moisture conditions of the soil and air temperature. The heat required by the digester to optimally produce biogas is, therefore, the sum of these two components. In conditions where excess heat is lost, additional energy input takes away from the net profitability of anaerobic digestion on the farm [15].

Efforts are now being made towards tapping renewable sources of energy [1]. Every household generate waste which if properly sorted, are biodegradable and are potential sources of bio-fuels. Jirarat et al. [16] stated that most households in Nigeria rely on wood as their main source of energy despite the huge waste generated from the kitchen and agricultural waste from agricultural practice like animal husbandry, food processing and land clearing activities. Some uses fossil fuels like kerosene and electricity which are scarce, expensive and contribute to global warning [1].

Methane is a big contributor to global warming and it is estimated to be 20 times more potent as a greenhouse gas than carbon dioxide. All biomass that is left to digest will release methane into the atmosphere and worsen the effects of global warming we are already experiencing. Using biogas can be of benefit to the environment and the farmland in many ways;

i. Using biogas will cause that less methane is released into the atmosphere;

ii. Using biogas will cause people to be less dependent on fossil fuels or wood in rural areas both of which releases Carbon dioxide when burned;

iii. Bio gas has been used as a fuel for heating and cooking in developing countries and to power buses and cars in developed countries just like liquid petroleum gas (LPG) is used;

iv. Treatment of wastes reduces water, air pollution, odours and destroys pathogens;

v. Application of digestate fulfils the phosphorus requirements of the crops and completes the nitrogen requirements from mineral fertiliser;

vi. Displacement of fossil fuels reduces $\mathrm{CO}_{2}$ Emissions ; vii. Additional earnings from waste treatment, production of energy and fertilisers, selling of green certificates;

viii. Improvement of the mechanical and nutrition properties of manure

ix. The biogas fuelled electric power provides added illumination of the greenhouse Effluent produced is also a good fertilizer;

x. Biogas powered lamp emits out $\mathrm{CO}_{2}$ which very good for the greenhouse plant production.

The objectives of this study were to:

i. Design 168-litres anaerobic digester and a 38-litres gas storage tank for house-hold cooking purpose;

ii. Construct the digester and the gas storage tank; and

iii. Generate biogas from blended plant (water hyacinth) and animal waste (cow dung, pig dung and poultry droppings), using anaerobic digestion.

\section{MATERIALS AND METHODS}

\subsection{Description of the Biogas Plant}

The Biogas plant (Figure 1) comprises of two major components (the digester tank and the storage tank) which were connected together with PVC pipes. The big tank (100 litres digester tank) consists of inlet valve at the top, where the raw materials are loaded through and is usually locked after the loading process to avoid escape of gas produced, and an outlet at the base, where the mixture of effluents and substrate is released from the tank. Pressure gauge is located at the top of the digester to measure the amount of gas produced. The storage tank (35 litres) also consists of three openings. One opening is at the top for the pressure gauge, while the other two openings are for inlet of biogas from digester and outlet of methane to the point of use.

The biogas digester unit has a main frame to which the digester is attached. The frame has three angle irons at the side to support the digester and the electric motor which is attached to one of the angle irons. The digester represents the centrepiece of the system. It is circular in shape it has the inlet valve, outlet valve, upper copular, the fermentation section, and the stirrer. The inlet valve is made of a funnel and a pipe. This is where the raw material is loaded; the stirrer which is powered by an electric motor stirs the mixture evenly for the fermentation process to be made easy. The upper copular is placed just above the fermentation tank. It is used to collect momentarily the gases coming from the decomposition of the fresh materials. Connected to the top of the digester is a pressure gauge which gives the amount of gas produced in the digester.

The pipes are sets of tubes used in transporting the produced gas from the digester to the different places where it would be used. The most appropriate pipe for biogas are they plimont, PVC and PE because of their high resistance to corrosion. The valves are used to control the movement of the gas into the pipes. They are installed in strategic points along the piping path. After the gas has been circulated through the valves it goes through a pipe to storage tank.

The filter is used for the purification of the gas. It is made of hydraulic pipes. It consists of little cylinder containing the filtering substances where every substance has a specific role. The carbon dioxide contained in the biogas is absorbed 
by layers of quicklime; the ammonia is absorbed by charcoal while the hydrogen sulphide is absorbed by iron filings.

The storage tank is also in a circular form fabricated from mild steel, with three openings which are the inlet of gas from the digester, the outlet of the gas to the point of use and the pressure gauge to know the amount of gas present in the storage tank.

\subsection{Design Considerations}

Biogas reactor unit is a convectional machine that would interact with different waste such as plant and animal wastes and also micro organism in the process of production, with some high degree of strength, pressure and precision, with consideration for low cost and maintainability.

The design considerations for the design of the biogas plant includes; strength, corrosion resistance, size of implement and affordability.

\subsection{Experimental Design}

This study was conducted to investigate the optimum production of methane gas from plant and animal wastes.
The machine was designed to increase the performance of the biogas production unit in terms of maximum gas production, for agricultural, domestic, and industrial uses. The materials used for production are locally available waste of animal (cow dung, pig dung, poultry dung) and plant wastes (water hyacinth, moringa leaves) with water were used in testing. Reading of the volume of gas produced will be observed from the pressure gauge and further test will be carried out on the gas produced

\subsection{Performance evaluation tests}

The following methods were used to evaluate the performance of the developed biogas production unit: volume of gas produced using plant waste alone, volume of gas produced using animal waste alone, volume of gas produced using the mixture of both plant and animal waste. Also test for quality of biogas produced was also carried out.

Table 1: Gas production using plant waste alone

\begin{tabular}{ccccc}
\hline $\begin{array}{c}\text { Digester size } \\
(\text { Litres })\end{array}$ & $\begin{array}{c}\text { Volume of plant waste } \\
(\mathrm{L} / \mathrm{kg} . \mathrm{TS})\end{array}$ & $\begin{array}{c}\text { Volume of water } \\
(\mathrm{L} / \mathrm{kg} . \mathrm{TS})\end{array}$ & $\begin{array}{c}\text { Retention period } \\
\text { (Days) }\end{array}$ & $\begin{array}{c}\text { Pressure produced } \\
(\mathrm{Bar})\end{array}$ \\
\hline 168 & 50 & 100 & 4 & $110 \mathrm{mmHg}=>0.178$ \\
\hline
\end{tabular}

Table 2: Gas production using animal waste alone

\begin{tabular}{ccccc}
\hline $\begin{array}{c}\text { Digester size } \\
\text { (Litres) }\end{array}$ & $\begin{array}{c}\text { Volume of animal } \\
\text { waste (L/kg.TS) }\end{array}$ & $\begin{array}{c}\text { Volume of water } \\
\text { (L/kg.TS) }\end{array}$ & $\begin{array}{c}\text { Retention period } \\
\text { (Days) }\end{array}$ & $\begin{array}{c}\text { Pressure produced } \\
(\text { Bar })\end{array}$ \\
\hline 168 & 70 & 50 & 4 & $110 \mathrm{mmHg}=>0.307$ \\
\hline
\end{tabular}

Table 3: Gas produced using plant and animal waste

\begin{tabular}{lllll}
\hline $\begin{array}{l}\text { Digester } \\
\text { size } \\
(\text { Litres })\end{array}$ & $\begin{array}{l}\text { Volume of plant } \\
\text { and animal } \\
\text { waste } \\
\text { (L/kg.TS) }\end{array}$ & $\begin{array}{l}\text { Volume of water } \\
\text { (L/kg.TS) }\end{array}$ & $\begin{array}{l}\text { Retention period } \\
\text { (Days) }\end{array}$ & $\begin{array}{l}\text { Pressure produced } \\
\text { (Bar) }\end{array}$ \\
\hline 168 & 90 & 55 & 4 & $110 \mathrm{mmHg}=>0.619$ \\
\hline
\end{tabular}

Table 4: Quality of gas produced

\begin{tabular}{lll}
\hline S/NO & Name of Gas & Percentage Produced $(\%)$ \\
\hline 1 & Methane $(\mathrm{CH} 4)$ & 59 \\
2 & Carbon-di-oxide $\left(\mathrm{CO}_{2}\right)$ & 25 \\
3 & Hydrogen sulphide $\left(\mathrm{H}_{2} \mathrm{~S}\right)$ & 3 \\
4 & Nitrogen gas $\left(\mathrm{N}_{2}\right)$ & 8 \\
5 & Oxygen gas $\left(\mathrm{O}_{2}\right)$ & 2 \\
6 & Hydrogen gas $\left(\mathrm{H}_{2}\right)$ & 3 \\
\hline
\end{tabular}

\subsubsection{Determination of the volume of gas produced} using plant waste alone

Fresh water hyacinth and moringa leaves were procured from a farm in Ijare community in Akure. The water hyacinth was chopped into smaller size for easy decomposition and was measured before being loaded into the digester, 45 litres of clean water was added to the 
digester. The stirrer which is powered by an electric motor stirs continuously at an interval of 5hours for easy decomposition. Other materials utilized were pressure gauge which indicates the amount of pressure generated in the digester.

\subsubsection{Determination of the volume of gas produced using animal waste alone}

Fresh cow dung, poultry dung, and pig dung were procured from FUTA farm. The three waste were weighed and loaded into the digester 30 litres of clean water was added and the stirrer was used to stir thoroughly for even mixture and easy decomposition. The stirrer stirs continuously at an interval of 5 hours and readings was taken pressure gauge which indicates the amount of pressure generate in the digester

\subsubsection{Determination of the volume of gas produced using the mixture of both plant and animal waste}

Fresh water hyacinth, moringa leaves cow dung, poultry dung, and pig dung was procured from FUTA farm and the farm at Ijare. The mixed waste were weighing 60 litres was loaded into the digester, 30 litres of clean water was added and the stirrer was used to stir thoroughly for even mixture and easy decomposition. The stirrer stirs continuously at an interval of 5 hours and readings was taken pressure gauge which indicates the amount of pressure generate in the digester

\subsubsection{Biogas quality measurement}

The methane content of biogas was determined and expressed as a percentage of its volume by the Beck method of biogas quality determination. A $5 \mathrm{ml}$ sample of gas was removed from the digester with the use of a syringe. The plunger of the syringe was pushed down to remove air contained in the syringe. The needle was then use to pierce through the rubber hose connecting the gas storage tank and cooker. The syringe plunger is then drawn to the fall position and the needle was withdrawn from the hose. The collected biogas was injected and analyser which contains $35 \%$ solution of potassium hydroxide. The potassium hydroxide absorbs the carbon dioxide content of the biogas and there was depression between the two levels of potassium hydroxide in $\mathrm{d}$ apparatus which reduced gradually until a stable reading was attained.

Apparatus used are; $5 \mathrm{ml}$ syringe; String tic; Flexible coupling ; Conical flask (1L); Inverted $60 \mathrm{ml}$ burette; Cork (air tight) ; 35\% KOH solution

The percentage methane was computed from equation

$\% \mathrm{CH}_{4}=\frac{\mathrm{X}_{1}-\mathrm{X}_{2} \quad \mathrm{x} 100 \%}{5}$

Where: $\mathrm{X}_{1}=$ initial reading on the analyzer $(\mathrm{ml})$

$\mathrm{X}_{2}=$ finial reading on the analyzer after the injector of biogas into the analyzer $(\mathrm{ml})$

\section{RESULTS AND DISCUSSION}

3.1 Result
The test results to determine the performance of the developed biogas production unit: volume of gas produced using plant waste alone, volume of gas produced using animal waste alone, volume of gas produced using the mixture of both plant and animal waste and quality of biogas produced are reported below.

\subsection{Discussion}

The result in Table 1 shows the actual volume of gas produced from plant waste at full capacity of the digester is 0.178 bar this indicates that the pressure of biogas is very low. While Table 2 shows gas produced from animal waste alone at full capacity of the digester was 0.307 bar this indicates that the pressure of biogas is also low, but still preferable than that of the plant waste. Table 3 shows the mixture of plant and animal waste which was also done at the digester full capacity gas produced was 0.619 bar which is averagely better than the other two. Looking at the result above it shows that to the mixture of plant and animal waste is the best substrate to use to attain optimum biogas production. Also the quality of gas test carried out shows that the quantity of methane present in the gas is more than $50 \%$. That means that the gas produced is of good quality.

\section{CONCLUSIONS}

In conclusion, the biogas production unit which was designed and tested was used to generate biogas anaerobically the biogas was produced using plant waste and animal waste. It can be seen that the 168 litres biogas plant is in a good working condition and can produce biogas optimally depending on the waste type to this view; the objective of this project work was achieved. And after different test it was discovered that the use of mixed substrate enhanced the biogas generation, and is the best method used to attain optimum production.

The following recommendations were made.

i. Further research on biogas technology should be adopted to provide fuel for cooking, lighting and running engines.

ii. Different types of biodegradable may be used.

iii. Government should subsidize the cost of locally fabricated biogas digester to make it affordable.

iv. Investigation into removal of hydrogen sulphide $\left(\mathrm{H}_{2} \mathrm{~S}\right)$ and carbon-di-oxide $\left(\mathrm{CO}_{2}\right)$ from biogas should be carried out.

v. The University management should endeavour to support the full production of this machine through grant to students for further research works.

\section{REFERENCES}

[1] FAO (2010): China: Small Biogas Technology Agricultural Service Bulletin No. 402 FAO

[2] Energy Commission of Nigeria. (1998). Rural renewable energy needs and five supply technologies. pp. $40-42$.

[3] Kozo, I; Hisajima, S; Darryl, R.J. (1996): Utilization of agricultural wastes for biogas production in Indonesia In: Traditional Technology for Environmental Conservation and Sustainable Development in Asia Pacific Region. 9th Ed. pp.137-138. 
[4] Fulford, D. (1998): Running a Biogas Programme. A hand book. "How Biogas Works". Intermediate Technology. Publication. 103-05 Southampton Row, London. WC 1B 4H, UK. pp. 33 - 34.

[5] El bassam, N. (1998): Energy Plant species-their use and impact on environment. London, James and James (Science

Publishers) Ltd. p. 321.

[6] Eze, J.I. (1995): Studies on generation of biogas from poultry droppings and rice husk from a locally fabricated biodigester. M.Sc. dissertation, University of Nigeria, Nsukka, pp. 64-65.

[7] Uzodinma, E.O, Ofoefule, A.U, Eze, J.I, Onwuka, N.D (2007): Biogas Production from blends of Agro-industrial wastes. Trends of Applied Science. Research, 2(6): 554-558.

[8] Mahnert, P; Heiernann, M; Linke, B. (2005): Batch and Semicontinuous Biogas Production from different grass species. Agricultural Engineering International. The CIGRE J., manuscript EE 05010, Vol.VII.

[9] Maishanu, S.M, Sambo, A.S. (1991): Biogas production from Leaf litter: A preliminary investigation. Niger. J. Solar Energy, 10: 138-144.

[10] Lucas, E.B, Bamgboye, A. (1998:. Anaerobic digestion of water hyacinth. Nigeria Journal of Renewable Energy. 6(1): $62-66$.

[11] Nwagbo, E.E, Dioha, I.J, Gulma, M.A. (1991): Qualitative investigation of Biogas from Cow and Donkey dung. Nigeria Journal of Solar Energy. 10: 145-149.

[12] Garba B, Zuru A.A, Sambo A.S. (1996): Effect of slurry concentration on biogas production from cattle dung. Nigeria Journal of Renewable Energy. 4 (2): 38 - 43.

[13] Zuru, A.A.; Saidu, H; Odum, E.A, Onuorah, O.A. (1998): A comparative study of biogas production from Horse, Goat and Sheep dung Nigeria. Journal of Renewable Energy, 6 (1\&2): 43 - 4

[14] Itodo I.N, Kucha E.I, (1998): An empirical relationship for predicting biogas yield from Poultry waste slurry. Nigeria Journal of Renewable Energy. Vol. 1\&2: $31-37$

[15] Hashimoto, A.G, Chen, Y.R, Varel, V.H. (1980): Theoretical aspects of methane production: State-of-the-Art. In proceedings "Livestock waste: A renewable resource. 4th International Symposium on Livestock Waste. ASAE, pp. $86-91$. 
Proc. of the Second Intl. Conf. on Advances in Bio-Informatics and Environmental Engineering - ICABEE 2015

Copyright $($ Institute of Research Engineers and Doctors, USA .All rights reserved.

ISBN: 978-1-63248-043-9 doi: 10.15224/ 978-1-63248-043-9-128

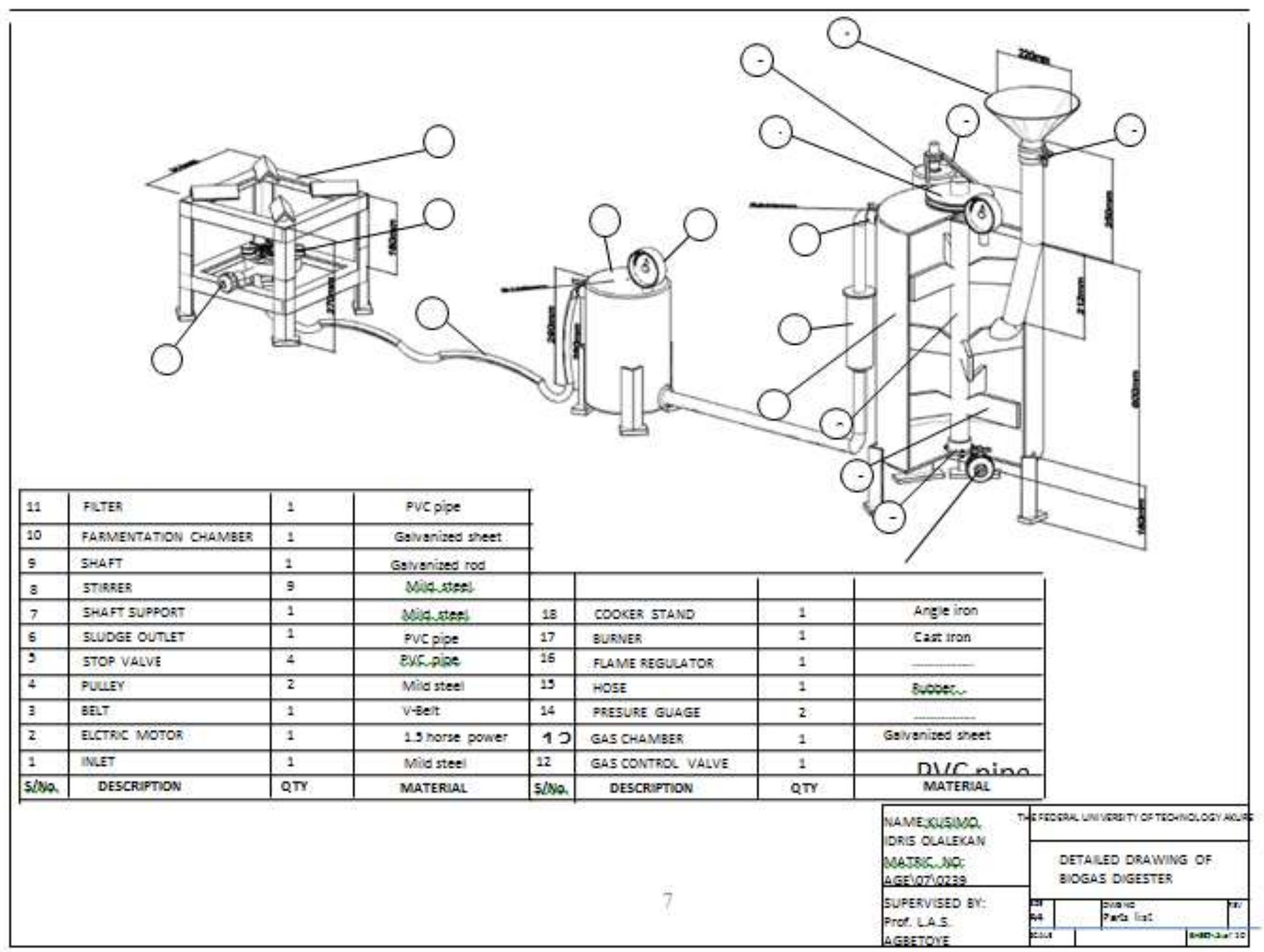

Figure 1: Exploded views of the Biogas production unit 